\title{
Medya Okuryazarlı̆ı̆ Dersi ve Televizyon Algısına Etkisi (Ankara Örneği)
}

\author{
Erol İlhan ${ }^{2}$ \\ Erhan Aydoğdu ${ }^{3}$ \\ Adalet Görgülï Aydoğdu ${ }^{4}$
}

Öz

Medyaya karşı bireyleri bilinçlendirmeyi ve bireylerin medya içeriklerini eleştirel bir bakış açısıyla değerlendirebilmesini amaçlayan medya okuryazarlı̆̆ı, uzun yıllardan bu yana dünyanın birçok ülkesinde müfredatlarda ders olarak yerini almıştır. Türkiye'de ise 2007-2008 eğitim-öğretim yılından itibaren seçmeli olarak okutulmaya başlanan ders ile ilgili tartışmalar, zorunlu olupolmaması ve dersin iletişim fakültesi mezunlarınca verilip-verilmemesi gibi hususlarda devam etmektedir.

Çalışmada; öğrencilerin medyaya özellikle televizyona yaklaşımı, içerikleri nasıl değerlendirdikleri, içerikleri değerlendirme konusunda eleştirel bir bakış açısı kazanıp, kazanamadıkları gibi hususlar üzerinde durularak, dersin öğrencileri bilinçlendirme düzeyi tespit edilmeye çalışılmıştır. Araştırma kapsamında Ankara'nın Mamak İlçesi'nden 75. Yıl İlköğretim Okulu, Keçiören'den Gülhane İlköğretim Okulu, Çankaya'dan Gülen Muharrem Pakoğlu Illköğretim Okulu, Altındağ'dan ìnsan Sungu İlköğretim Okulu ve Yenimahalle'den Yeşilevler İlköğretim Okulları'nın her birinden dersin uygulanmakta olduğu ikişer şube tesadüfi örnekleme yoluyla seçilmiş ve toplam 258 öğrenciye anket uygulanmıştır.

Çalışma sonucunda; medya okuryazarlığı dersinin yararlı ve gerekli bir ders olduğu saptanmış, öğrencilerin medya ile içeriklerine karşı eleştirel bir bakış açısı kazandığı görülmüştür.

Anahtar Kelimeler: Medya Okuryazarlığı, Medya, Kitle İletişim Araçları, İlköğretim, Bilinç.

\section{Media Literacy Course and Its Effect on Television Perception (Ankara Sample)}

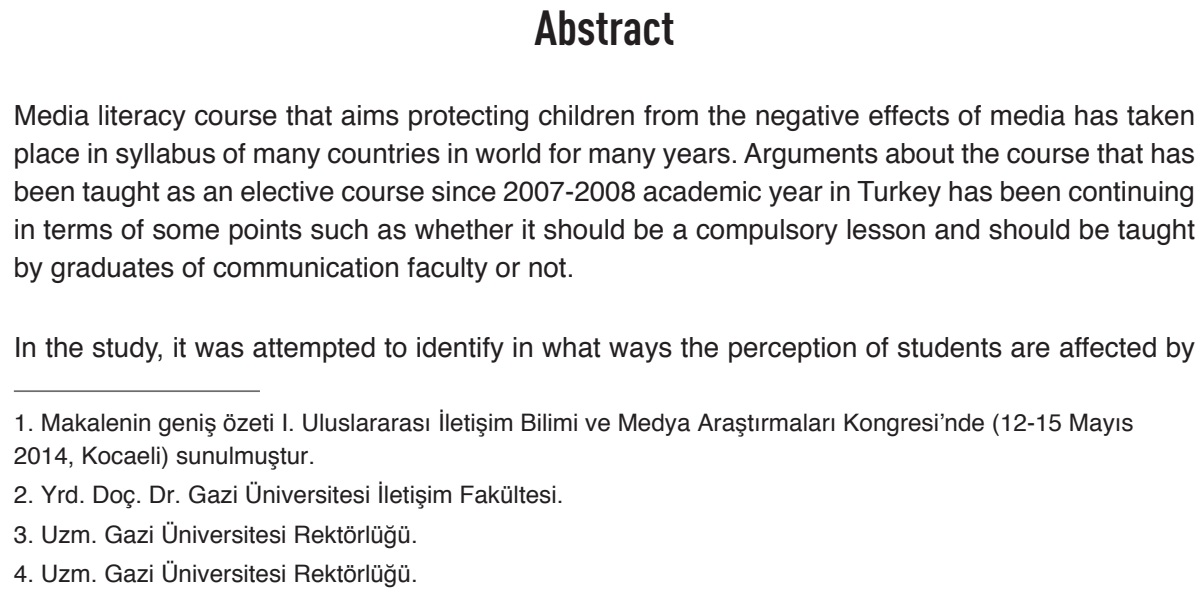

Media literacy course that aims protecting children from the negative effects of media has taken place in syllabus of many countries in world for many years. Arguments about the course that has been taught as an elective course since 2007-2008 academic year in Turkey has been continuing in terms of some points such as whether it should be a compulsory lesson and should be taught by graduates of communication faculty or not.

In the study, it was attempted to identify in what ways the perception of students are affected by

1. Makalenin geniş özeti I. Uluslararası İletişim Bilimi ve Medya Araştırmaları Kongresi'nde (12-15 Mayıs 2014, Kocaeli) sunulmuştur.

2. Yrd. Doç. Dr. Gazi Üniversitesi İletişim Fakültesi.

3. Uzm. Gazi Üniversitesi Rektörlüğü.

4. Uzm. Gazi Üniversitesi Rektörlüğü. 
this course by considering their approach to media especially to television, how they evaluate the contents and if they are aware of its negative effects. Within the scope of the survey, a questionnaire was made to 258 students who were chosen coincidentally from two classes of the schools in Ankara named 75.century Primary School (Mamak), Gülhane Primary School (Keçiören), Gülen Muharrem Pakoğlu Primary School (Çankaya), İhsan Sungu Primary School (Altındağ) and Yeşilevler Primary School (Yenimahalle).

As a result of the study, it was determined that media literacy course is a beneficial and essential lesson, and it was seen that the students gained a critical viewpoint against media and its content.

Keywords: Media Literacy, Media, Mass Media, Primary School, Consciousness. 
ortaya atılmış bir kavram olarak ifade etmiştir. Taşkıran (2007: 91) ise medya okuryazarlığının amacıyla ilgili olarak yaptığı açıklamada; "medya tüketimi sürecini faal ve eleştirel bir sürece dönüştürmek"ten bahsetmiştir.

Medya mesajlarıyla çevrili bir dünya içinde bulunan bireyin, medyanın içeriklerini eleştirel bir şekilde değerlendirebilmesinin gerekliliğinden, toplumsal yaşamda düzenin sağlanması ve demokratik toplum oluşturmak gibi birbirinden farklı birçok konuda medya okuryazarlığı bir intiyaç olarak ortaya çıkmıştır. Bu nedenle medya okuryazarlığının amaçları ile ilgili olarak yapılan açıklamaların birbirinden farklı olduğu dikkati çekmektedir. Tokgöz (2010:154) medya okuryazarlığının amacını "gerçekliğin inşa edilebilme aracı olarak kullanıldığının farkında olan etkin katılımcılar yaratmak" olarak ifade ederken, Binark ve Bek'e (2010: 10-11) göre medya okuryazarlığının amacı "yurttaşın toplumsal, kültürel, siyasal ve ekonomik alanlarda etkin aktör olarak her türlü karar mekanizmasında yer almasını, aldığı kararların da sorumluluğunu üstlenmesini, öz-düşünümsel bir bilinç ile sorumluluk etiği geliştirmesini desteklemektir."

Avrupa Medya Okuryazarlığı Merkezi (European Centre for Media Literacy) ise medya okuryazarlığının amaçlarını; "medyanın fikir, bilgi ve haberi bir başkasının bakış açısıyla nakletmek üzere kurulduğunu anlamak", "duygusal etki oluşturmak için özel tekniklerin kullanıldığını anlamak", "bu tekniklerin amaçlandıkları ve doğurdukları etkilerin ayırdına varmak", "medyanın bazı kişilerin yararına çalışı̆̆ı̆ı, bazılarını ise dışladığını anlamak", "alternatif bilgi ve eğlence kaynakları aramak", "medyayı kendi yararı ve zevki için kullanmak", "edilgen olmak yerine aktif olmak", "yeni öğrenme kültürü olan dijital okuryazarlığa hazırlanmak" şeklinde sıralamıştır (Pekman, 2011: 41).

İnceoğlu'nun medya okuryazarlığının amaçlarıyla ilgili olarak yaptığı açıklama, Tokgöz'den, Taşkıran'dan ve Avrupa Medya Okuryazarlığı Merkezi'nden farklı olarak medya okuryazarlığından toplumsal düzenin sağlanması açısından da yararlanılabileceğini ortaya koymaktadır. İnceoğlu'na (2011: 21) göre medya okuryazarlığının amaçları "demokrasi, yurttaşıłık bilinci ve siyasal katııımı teşvik etme", "ırk, sınıf ve toplumsal cinsiyet ayrımcılığını asgariye indirme", "uyuşturucu kullanımışiddeti önleme", "eğitim düzeyini iyileştirme" ve benzerleridir.

\subsection{Eleștirel Medya Okuryazarlığı}

Medya okuryazarlığı ile ilgili yapılan tanımlara bakıldığında bir yanda "medyayı kullanabilen bireyler yetiştirmekten" ve "bireyleri medyanın zararlı etkilerinden korumaktan", diğer yanda ise "medyayı sorgulayan ve eleştirebilen bireyler" yetiştirmekten bahsedilmektedir. Tanımlamalardaki bu farklıık medya okuryazarlığı alanında hâkim olan iki farklı yaklaşımdan kaynaklanmaktadır. Bu yaklaşımlardan birisi ticari/ana akım/geleneksel medya okuryazarlığı iken diğeri eleştirel medya okuryazarlı̆̆ıdır.

Ana akım medya okuryazarlığında bireyleri medyanın zararlı etkilerinden korumak ön plandayken, eleştirel medya okuryazarlığında bireyleri medyanın zararlı etkilerinden korumanın da ötesinde medya içeriklerine karşı eleştirel bakış açısı kazandırmak hedeflenmektedir. İnal (2009: 89) eleştirel yaklaşımı "eleştirel", önyargı, önyargılı temsiller, yanlış ifadeler ve hatalar ve/veya bir metnin değer ihtiva eden mesajlarını ortaya çıkarmak için öğrenilmiş medya becerilerini kullanarak kitle iletişim araçları üzerinde uyanık bir gözleme/izleme süreci” olarak tanımlamaktadır. Hobbs'a( 2004:136) göre, medya okuryazarlığına, medya okuryazarı olmanın merkezinde yer alan "izlenilen, görülen ve okunanlarla ilgili olarak eleştirel sorular sorma"yı eklemek gerekmektedir. Zaten 
medya okuryazarlığının temel hedefi, tüm medyaya dair eleştirel özerkliktir. Eleştirel özerkliğin vurguladığı şey, bilgilenmiş yurttaşıı, estetik değerlendirme ve ifade, sosyal sorumluluk, kendine saygı ve tüketimde yeterliliktir (Aufderheide'den akt. İnal, 2009:90). Binark ve Bek (2010:111), eleştirel medya okuryazarı olan bir yurttaşın, medya metinlerinde dolaşıma sokulan uzlaşımları ve başat kodları okumakla kalmayarak, bunların gündelik yaşamdaki köklerinin de farkına varabileceğini ifade etmektedir.

\subsection{Dünyada ve Türkiye'de Medya Okuryazarliğı}

Dünyada özellikle son 30-40 yıldır tartışılmakta olan medya okuryazarlığına verilen önem ve konuyla ilgili yapılan çalışmalar ülkeden ülkeye farklıık göstermektedir. İngiltere, Avustralya, Güney Afrika, Kanada ve Amerika gibi ülkeler medya okuryazarlığı alanında öncü ülkeler durumundadır.

Medya okuryazarlığı 1982 yılında UNESCO'nun gerçekleştirmiş olduğu bir toplantının bildirisinde yerini almış ve toplantı kavramın yaygınlaşmasına büyük katkıda bulunmuştur.

Avrupa Birliği üye devletleri arasında medya okuryazarlığıyla ilgili olarak çeşitli uygulamalar görülmesine rağmen, kavram 2000 yılında Lizbon'da gerçekleşen zirve ile AB'nin gündemine girmiştir. Zirvede; yeni enformasyon ve iletişim teknolojisine dayalı bilgi toplumu ve bilgi ekonomisinin şekillendirildiği geleceğin Avrupası'nı ve yaşam boyu öğrenimin desteklenmesi, eğitime genel bütçede ayrılan payın artırıması, enformasyon teknolojilerini kullanma becerilerinin geliştirilmesi üzerinde durulmuştur (Binark ve Bek, 2010:73).

Avrupa Birliği Konseyi, Belçika Fransız Topluluğu Medya Okuryazarlığı Yüksek Konseyi'nin 0203 Aralık 2010 tarihlerinde düzenlediği "Hepimiz İçin Medya Okuryazarlığı" konulu uluslararası konferans ise tüm dünyadan konuyla ilgili 300 uzmanı bir araya getirmiştir. Konferans sonrasında oluşturulan "Yaşam Boyu Medya Okuryazarlığı Hakkında Brüksel Deklarasyonu" yürütülecek eğitim faaliyetlerine, her vatandaşın medyayı kullanma yeteneğine, vatandaşın medya okuryazarlığı eğitimine erişimine, araştırmalara ve Avrupa medya politikalarına ilişkin bir tavsiyeler bütünü sunmuştur.

Türkiye'de medya okuryazarlığı her ne kadar 2000'li yıllarda tartışılmaya başlansa da medya okuryazarlığı ile ilgili ilk uygulamalar daha eski yıllara dayanmaktadır. 1911 yılında Mehmet Said Paşa'nın İstanbul Sabah Matbaası'ndan çıkan Gazete Lisanı adlı yapıtı medya okuryazarlığı çalışmaları açısından bir ilk örnek olarak değerlendirilmektedir (Özarslan, 2008:VII). 1937 yılında Muvaffak Uyanık tarafından hazırlanan ve basımı gerçekleştirilen Yeni Okulun Ders Vasıtalarından Gazete ise medya okuryazarlığı konusunda hazırlanan bir başka yapıttır (Uyanık, 2007:V). Uyanık, çocukların gazete okuma alışkanlıklarıyla ilgili olarak, Ankara'da yedi ilkokulda, üçüncü, dördüncü ve beşinci sınıflarda okuyan 283 öğrenciye anket uygulayarak bulguları kitap olarak yayınlamıştır (Güngör, 2011: 305-306).

Bu öncü adımlara rağmen Türkiye'de medya okuryazarlığı ancak 2003 yılında düzenlenen bir iletişim şûrasında gündeme gelmiştir. 20-21 Şubat 2003 tarihlerinde Radyo ve Televizyon Üst Kurulu (RTÜK) tarafından düzenlenen İletişim Şûrası'nda medya okuryazarlığı konusuna değinilerek, şûranın sonuç bildirgesinde medya okuryazarlığına yer verilmiştir.

MEB Talim ve Terbiye Kurulu (TTK) Başkanlığı, RTÜK ve iletişim fakültesi uzmanlarından oluşan bir komisyon tarafından 2006 yılında "Medya Okuryazarlığı Dersi Taslak Öğretim Programı 
ve Öğretmen Kılavuzu" hazırlanmıştır. "Öğretim Kurumlarına Medya Okuryazarlığı Dersi Konulmasına Dair İşbirliği Protokolü” ise 22 Ağustos 2006'da RTÜK ile MEB TTK Başkanlığı arasında imzalanmıştır. 31 Ağustos 2006 tarihinde de MEB TTK Başkanlığı'nda yapılan görüşmede "illköğretim Seçmeli Medya Okuryazarlığı Dersi Öğretim Programı" kabul edilmiştir (RTÜK, 2007).

Medya okuryazarlığı dersi, 2006-2007 öğretim yılında pilot olarak seçilen Adana-Seyhan Dumlupınar İlköğretim Okulu, Ankara-Çankaya Ahmet Vefik Paşa İlköğretim Okulu, ErzurumMerkez Barbaros Hayrettin Paşa İlköğretim Okulu, İstanbul-Bakırköy Şehit Pilot Muzaffer Erdönmez İlköğretim Okulu ve İzmir-Karşıyaka METAŞ İlkoğretim Okulu'nda toplam 780 öğrenciye verilmeye başlanmıştır.

Medya okuryazarlığı dersini bu pilot okullarda verecek olan 20 sosyal bilgiler öğretmeni için Ankara'da 7-10 Eylül 2006 tarihleri arasında dört gün süreyle "Eğitici Eğitimi Programı" gerçekleştirilmiştir.

2007-2008 eğitim-öğretim yılından itibaren müfredatlarda seçmeli ders olarak yer almaya başlayan medya okuryazarlığı 6'ncı, 7'nci ve 8'inci sınıfların herhangi birinde, haftada bir seçilebilmekte ve bir ders saati okutulmakta iken 25.06.2012 tarihli ve 69 sayılı Kurul Kararı ile kabul edilen Ilköğretim Okulları Haftalık Ders Çizelgesi ile dersin 7'nci veya 8'inci sınıflarda ve iki ders saati olarak okutulması kararlaştırımıştır.

Türkiye'de uygulanmakta olan İlköğretim Medya Okuryazarlığı Dersi Programı'na bakıldığında toplam 8 üniteden oluşan programın bir ünitesi "İnternet Sanal Dünya" adını taşımaktadır. Bu ünitenin programdaki oranı \% 12.5'tir. Aynı programda "Televizyon" ve "Aile Çocuk ve Televizyon" olmak üzere televizyonla ilgili iki ünite yer almaktadır. Televizyonla ilgili ünitelerin programdaki oranı ise \% 29.5'tir (MEB ve RTÜK, 2007: 39). Yalnız Milli Eğitim Bakanlığı Talim Terbiye Kurulu Başkanlığının 11.12.2013 tarih ve 239 sayılı kararı ile bu program yenilenmiştir. 2014-2015 eğitimöğretim yılından itibaren uygulanacak olan programın önceki gibi (televizyon, internet, gazete vb.) araç esaslı olmadığı, beceri (erişim, çözümleme, değerlendirme ve üretim) temelli bir yaklaşımı esas aldığı belirtilmektedir. Eğlence Aracı Olarak Medya Alanı 'Eğlencem Medya', Bilgi Kaynağı Olarak Medya Alanı 'Medyaya Soru Soruyorum', ve ‘Önce Bir Düşüneyim', Katılım Ortamı Olarak Medya Alanı ise ‘Benim Medyam' ünitelerinden oluşmaktadır.

\section{Televizyon ve Çocuk}

İnsanların en çok kullandığı kitle iletişim araçlarının başında televizyon gelmektedir. Kitle iletişim araçlarının etkileriyle ilgili olarak yapılan araştırmalarda, özellikle televizyonun zihinsel açıdan olgunluğa erişmemiş olan çocuklar üzerinde olumsuz etkileri olabileceğine dikkat çekilmektedir.

Televizyon bireylere gerçek olmayan, kurgulanmış bir dünya sunmaktadır. Televizyondaki dünya ile gerçek dünya arasındaki ayrıma dikkat çeken Mutlu (1999: 97), televizyonun ekrandaki dünyayı gerçek dünyanın oluşturucu unsurları ve ilişkileriyle kurmasına rağmen, televizyonun temsili doğasının ve dramatik temsili yapısının gerçekliğin ekranlarda olduğu gibi yansımasına elvermeyeceğini belirtmektedir.

Condry'ye göre; televizyonun görüntüler sayesinde radyoya göre çok daha fazla enformasyon içermesi ve gazeteye göre de anlaması daha kolay olup, izlemek için okuryazarlık dahi 
gerektirmemesi nedeniyle televizyon kitle iletişiminin vazgeçilmez bir unsuru olmuştur (Condry'den akt. Treske, 2011: 28).

RTÜK'ün (2009) yaptığı "Televizyon İzleme Eğilimleri Araştırması” Türkiye'de televizyona olan bağımlılığın ciddi bir boyuta ulaştığını gözler önüne sermektedir. Bu araştırmaya katılanların \%54.6'sının evinde 1, \% 36.4'ünün evinde 2 ve \%9'unun evinde ise 3 veya daha fazla televizyon bulunmaktadır. Ayrıca hafta içi günlük ortalama televizyon izleme sürelerine bakıldığında, araştırmaya katılanların \%20.5'i 3 saat televizyon izlerken, \%17.2'si 2 saat, \%16.4'ü ise 4 saat televizyon izlemektedir. 10 saat ve üzeri televizyon izleyenlerin oranı ise \%4.5 olarak saptanmıştır. Hafta sonu günlük televizyon izleme süreleri ise \%15.8 ile 6 saat, \%15.7 ile 4 saat, \%15.6 ile 2 saat ve \%15.2 ile 3 saattir. 10 saat ve üzeri televizyon izleyenlerin oranı \%5.9'tur.

Televizyonla ilgili olarak yapılan birçok araştırma, bu kitle iletişim aracının birey ve toplum üzerinde birçok olumsuz etkisinin olduğunu ortaya koymuştur. Özer'in (2011:8) Türkiye'deki televizyon haberleriyle ilgili yaptığı araştırmaya göre haberlerin yüzde 20'si şiddet içeriklidir ve televizyon şiddet yoğun bir dünyadır. Bu şiddetin toplum üzerindeki olumsuz etkisini görmek açısından RTÜK'ün Televizyon İzleme Eğilimleri Araştırması'nın sonuçları önem taşımaktadır. $\mathrm{Bu}$ araştırmaya katılanların \%79,6'sı televizyonun toplumda şiddeti artırdığını belirtmiştir. Televizyonda yer alan şiddet içerikli yayınlarla ilgili olarak Taylan (2011) tarafından yapılan bir diğer araştırmada ise şiddet içerikli televizyon programlarına fazlaca maruz kalan gençlerin, dünyayı acımasız ve tehlikeli buldukları ve sorunların çözümünde şiddete eğilimli oldukları tespit edilmiştir.

Konya'daki yerel televizyonlarla ilgili yapılan bir diğer araştırmaya göre ise bireylerin boş zamanlarını değerlendirmede en etkili araç, televizyondur. Ayrıca, yerel televizyonlarda demokratikleşme, bilgi verme, önyargısız olma, herkese hitap etme, toplum temsil kapasitesi, çağdaş olma, güvenilir olma, toplum gerçeklerini yansıtma, haberleri inandırıcı bulma, haberleri ciddi bulma, kaliteli programlara sahip olma ve bilgilendirici, eğlendirici, eğitici programlar açısından sorunlar bulunduğu saptanmıştır (Ayhan, 2011:151-152).

İnsanların günlük yaşamının bir parçası haline gelmiş olan televizyonun toplum üzerindeki etkilerine değinirken, televizyonun çocuklar üzerindeki etkilerini ortaya koymak için ayrı bir paragraf açmak gerekmektedir.

RTÜK'ün "Televizyon İzleme Eğilimleri Araştırması”nın ortaya koyduğu televizyon izleme sürelerini, sadece bir bireyin televizyon izleme süresi olarak değerlendirmek doğru olmayabilir. Televizyonun genelde ailenin bir araya geldiği oturma odalarında olduğunu düşündüğümüzde, büyüğünden küçüğüne tüm aile bireyleri televizyondan uzak kalamayabilmektedir. Üstelik RTÜK'ün "İlköğretim Çağı Çocukları İçin TV İzleme Araştırması” durumun çocuklar açısından ciddiyetini açık bir şekilde ortaya koymuştur. Kendine ait odası bulunan öğrencilerin \%29,3'ünün odasında da televizyon bulunmaktadır. Bu çocukların televizyon programı seçiminde ve izleme süresinde daha serbest olacağı da aşikardır.

Çocukların sosyalleşmesi ve kişiliğinin gelişmesinde aile, okul ve sosyal çevrenin yanında kitle iletişim araçlarının etkisi görmezden gelinemez. Günümüzde kitle iletişim araçları ve özellikle televizyon, çok farklı kaynaklardan iletiler sunmak suretiyle çocuğun toplumsal kimliğinin biçimlenmesinde dolayısıyla sosyalleşmesinde etkili bir rol oynamaktadır (Kaya ve Tuna; 2008: 163). Hatta televizyonun yazılı basına göre her eve girmesi ve daha yaygın olması nedeniyle çocuklar edindikleri enformasyonu, kültürü ve dünya görüşünü ailesinden çok televizyondan 
alabilmektedir (Wilson'dan akt. Treske, 2011:28).

Kuruoğlu ise "Televizyonun Çocuklar Üzerindeki Olumsuz Etkileri" başlıklı makalesinde Türkiye'de gazete ve kitap okuma oranın düşüklüğüne dikkat çekerek, okuma ve düşünme geleneğinin yerleşmediği toplumlarda televizyondan daha yoğun bir şekilde etkilenileceğini belirtmiştir. Kuruoğlu aynı makalede televizyonun çocuklar üzerindeki etkilerini "tüketim toplumu bireyi olmaları üzerine etkileri", "cinsel kimliğin oluşması ve karşı cinsle olan ilişkiler üzerine etkisi", "anne ile ilişkisi üzerine etkisi”, "baba ile ilişkisi üzerine etkisi", "şiddet eğilimlerine etkisi", "okumaya, düşünmeye ve başarıya etkisi", "kültürel yabancılaşmaya etkisi", "dildeki yozlaşmaya etkisi", "kendi kimliklerinin bağımsız ve özgün bir biçimde oluşmasına etkisi" ve "çocukluğun yitirilişi ve masumiyetin yokoluşuna etkisi" olmak üzere on başılı altında toplamıştır. (www. scholar.google.com.tr)

Oğuz da medyanın özellikle de televizyonun kültürün aktarımında taşıdığı öneme dikkat çekmektedir. Medyanın en etkili kültürlenme alanı olduğunu belirten Oğuz konuyla ilgili olarak şunları ifade etmektedir: "Medyanın etkili olduğu kültürlenme süreci sargın öğrenmenin bir parçasıdır. Aynı zamanda medya, en etkili kültürlenme alanıdır. Çünkü rastlantısal olarak açılan bir kanalda, izledikleriniz doğrultusunda kültürleniyorsunuz. Mesela üniversiteye gelen çocuklarımıza, 'cadılar bayramı nedir' diye sorduğumuzda, cadılar bayramının ne olduğu çok iyi bir şekilde anlatılabilirken, 'çiğdem günü nedir', 'cemre nedir' diye sorduğumuzda herhangi bir bilgiye sahip olmadıklarını görüyoruz. Buna benzer yüzlerce örnek var. Bu şunu gösteriyor ki, medya kültürlenmede çok iyi bir yere sahip. Ama şu bir gerçek: Çizgi film ve benzeri programlar dâhil olmak üzere medyanın kendi kültürümüzü gelecek kuşaklara aktarmak açısından yeterli enstrümanlarla konuşmadığını söyleyebiliriz (Aydoğdu, 2014:31).

Televizyonun yarattığı bağımlııı ise çocuklarla ilgili bir başka sorunu daha ortaya çıkarmaktadır. Zamanını ekran başında harcayan çocuk, sosyal ve psikolojik gelişimi açısından önem taşıyan arkadaşlık ortamlarından uzak kalacaktır. Bu da çocukların içe kapalı bir insan haline gelmelerine yol açmaktadır (Kaya ve Tuna, 2008:164).

Treske'ye göre televizyon tek başına sorunların sebebi olmayıp, bu karmaşık sürecin sadece bir parçasıdır. Bütün öneri, düzenleme ve yasalara rağmen, bu günün çok kanallı ve değişik mecralı iletişim ortamında en önemli çözüm eğitim olmaktadır (Treske, 2011: 35). Dolayısıyla ilköğretim ikinci kademede müfredatta yer alan medya okuryazarlığı dersi bireyleri bilinçlendirmek, seçici olabilmelerini sağlamak, hatta eleştirel bir bakış açısına kavuşturabilmek açısından büyük önem taşımaktadır.

\section{Yöntem}

\subsection{Evren ve Örneklem}

Medya okuryazarlığı dersinin çocukların televizyon algısına etkisiyle ilgili olarak yapılan bu araştırmada, Ankara il merkezinde bir alan araştırması yapılmıştır. Araştırmanın örneklemini, bu dersi 8'inci sınıfta uygulamakta olan ve farklı ilçelerde yer alan 75. Yıl İlköğretim Okulu, Gülhane İlköğretim Okulu, Gülen Muharrem Pakoğlu İlköğretim Okulu, İhsan Sungu İlköğretim Okulu ve Yeşilevler Illköğretim Okulu oluşturmuştur. Bu okulların her birinden medya okuryazarlığı dersinin okutulmakta olduğu ikişer şube tesadüfi olarak seçilmiş ve bu şubelerde bulunan tüm öğrenciler örnekleme dâhil edilmiştir. Ayrıca, araştırmanın yapılması için dönem sonu beklenmiştir. 
Öğrencilerin 85'inin (\% 32,9) günde 1-2 saat arası televizyon izlediği görülmektedir. Öğrencilerin 77 'si $(\% 29,8)$ 2-3 saat arası, 41'i $(\% 15,9)$ ise 3-4 saat, 33'ü (\% 12,8) 1 saatten az, 22 'si ise $(\% 8,5)$ 4 saat ve üzeri zamanı televizyon karşısında geçirmektedir.

Tablo 2. Öğrencilerin Televizyon İzleme Amaçları

\begin{tabular}{|l|l|l|}
\hline Amaç & Öğrenci Sayısı & Yüzde \% \\
\hline Eğlenmek & 121 & 46,9 \\
\hline Boş zaman değerlendirmek & 81 & 31.4 \\
\hline Bilgi edinmek & 42 & 16.3 \\
\hline Diğer & 14 & 5.4 \\
\hline Toplam & 258 & 100 \\
\hline
\end{tabular}

Araştırmaya katılanların $121^{\prime} i(\% 46,9)$ televizyonu eğlenmek için izlemektedir. 81 öğrenci ise (\% $31,4)$ televizyonu boş zaman değerlendirmek için izlediğini belirtirken, 42 öğrenci $(\% 16,3)$ bilgi edinmek, 14 öğrenci $(\% 5,4)$ ise diğer sebeplerden dolayı televizyon izlemektedir.

Tablo 3. "Televizyon İzlerken Program Seçiminde Akılı İşaretlere Dikkat Edilmelidir"

\begin{tabular}{|l|l|l|}
\hline & Öğrenci Sayısı & Yüzde \% \\
\hline Tamamen Katılıyorum & 185 & 71.7 \\
\hline Kısmen Katılıyorum & 30 & 11.6 \\
\hline Kararsızım & 22 & 8.5 \\
\hline Kısmen Katılmıyorum & 5 & 1.9 \\
\hline Tamamen Katılmıyorum & 16 & 6.2 \\
\hline Toplam & 258 & 100 \\
\hline
\end{tabular}

"Televizyon izlerken program seçiminde akıllı işaretlere dikkat edilmelidir" ifadesine öğrencilerin 185’i (\% 71,7) "tamamen katılıyorum", 30’u (\% 11,6) “kısmen katılıyorum”, 22'si (\% 8,5) "kararsızım", 16’sı (\% 6,2) "tamamen katılmıyorum" ve 5’i $(\% 1,9)$ ise "kısmen katılmıyorum" yanıtını vermiştir.

Tablo 4. "Medya Okuryazarlığı Dersi Televizyon Programı Seçimimde ve Televizyona Ayırdığım Zamanda Değişiklik Meydana Getirdi”

\begin{tabular}{|l|l|l|}
\hline & Öğrenci Sayıs & Yüzde \% \\
\hline Tamamen Katılıyorum & 93 & 36 \\
\hline Kısmen Katılıyorum & 83 & 32.2 \\
\hline Kararsızım & 45 & 17.4 \\
\hline Kısmen Katılmıyorum & 15 & 5.8 \\
\hline Tamamen Katılmıyorum & 22 & 8.5 \\
\hline Toplam & 258 & 100 \\
\hline
\end{tabular}




\begin{tabular}{|l|l|l|}
\hline Tamamen Katılmıyorum & 16 & 6.2 \\
\hline Toplam & 258 & 100 \\
\hline
\end{tabular}

"Bilinçli bir medya kullanıcısı olabilmek için medya okuryazarlığı dersini almak gerekmektedir" ifadesine öğrencilerin 138'i (\% 53,5) "tamamen katılıyorum", 57'si (\% 22,1) "kısmen katılıyorum", 34'ü (\% 13,2) "kararsızım", 16’sı (\% 6,2) "tamamen katılmıyorum" ve 13'ü (\% 5) "kısmen katılmıyorum" yanıtını vermiştir.

Tablo 8: "Medya Metinleri İdeolojik Mesajlar İçermektedir"

\begin{tabular}{|l|l|l|}
\hline & Öğrenci Sayısı & Yüzde \% \\
\hline Tamamen Katılıyorum & 108 & 41.9 \\
\hline Kısmen Katılıyorum & 67 & 26 \\
\hline Kararsızım & 50 & 19.4 \\
\hline Kısmen Katılmıyorum & 14 & 5.4 \\
\hline Tamamen Katılmıyorum & 19 & 7.4 \\
\hline Toplam & 258 & 100 \\
\hline
\end{tabular}

"Medya metinleri ideolojik ve değersel mesajlar içermektedir" ifadesine öğrencilerin 108'i (\% 41,9) “tamamen katılıyorum”, 67'si (\% 26) “kısmen katılıyorum” 50'si (\% 19,4) “kararsızım”, 19'u (\% 7,4) "tamamen katılıyorum", 14'ü (\% 5,4) ise "kısmen katılmıyorum" yanıtını vermiştir.

Tablo 9. "Medyanın Sunduğu Dünya Gerçek Değildir, Bir Kurgudur"

\begin{tabular}{|l|l|l|}
\hline & Öğrenci Sayısı & Yüzde \% \\
\hline Tamamen Katııyorum & 83 & 32.2 \\
\hline Kısmen Katııyorum & 65 & 25.2 \\
\hline Kararsızım & 48 & 18.6 \\
\hline Kısmen Katılmıyorum & 26 & 10.1 \\
\hline Tamamen Katılmıyorum & 36 & 14 \\
\hline Toplam & 258 & 100 \\
\hline
\end{tabular}

"Medyanın sunduğu dünya gerçek değildir, bir kurgudur" ifadesine öğrencilerin 83’ü (\% 32,2) "tamamen katılıyorum", 65”i (\% 25,2) "kısmen katılıyorum", 48'i (\% 18,6) "kararsızım", 36'sı (\% 14) "tamamen katılmıyorum" ve 26 'sı (\% 10,1) "kısmen katılmıyorum" şeklinde cevap vermiştir. 
"Medya okuryazarlığı dersi medya konusunda bilgilendiricidir, medyayı doğru anlamayı sağlamaktadır" ifadesine öğrencilerin 174'ü (\% 67,4) "tamamen katılıyorum", 51'i (\% 19,8) "kısmen katılıyorum", 17'si (\% 6,6) "kararsızım", 11'i (\% 4,3) "tamamen katılmıyorum", 5’i (\% 1,9) ise "kısmen katılmıyorum" demiştir.

Tablo 13. "Medya Okuryazarlığı Dersi Medyayı Sorgulamayı ve Medya İçeriklerine Karşı Eleştirel Bakış Açısı Kazanmayı Sağlamaktadır”

\begin{tabular}{|l|l|l|}
\hline & Öğrenci Sayısı & Yüzde \% \\
\hline Tamamen Katılıyorum & 136 & 52.7 \\
\hline Kısmen Katııyorum & 64 & 24.8 \\
\hline Kararsızım & 36 & 14 \\
\hline Kısmen Katılmıyorum & 10 & 3.9 \\
\hline Tamamen Katılmıyorum & 12 & 4.7 \\
\hline Toplam & 258 & 100 \\
\hline
\end{tabular}

"Medya okuryazarlığı dersi medyayı sorgulamayı ve medya içeriklerine karşı eleştirel bakış açısı kazanmayı sağlamaktadır" maddesine öğrencilerin 136'sı (\% 52,7) "tamamen katıııorum", 64'ü (\% 24,8) "kısmen katılıyorum", 36'sı (\% 14) "kararsızım", 12'si (\% 4,7) "tamamen katılmıyorum" ve 10 'u (\% 3,9) "kısmen katılmıyorum" görüşünü belirtmiştir.

\section{Sonuç ve Değerlendirme}

Medya okuryazarlığı ile medya içeriklerini eleştirel bir bakış açısıyla değerlendirebilen ve tekrar iletide bulunabilen, aktif medya kullanıcıları yetiştirmek amaçlanmaktadır. Bireylerin birer medya okuryazarı olabilmesi için uzun yıllardan bu yana dünyanın birçok ülkesinde müfredatlarda ders olarak yerini alan medya okuryazarlığı, Türkiye'de ise 2007-2008 eğitim-öğretim yılından itibaren ilköğretim ikinci kademede seçmeli ders olarak okutulmaya başlanmıştır. Ancak, dersin zorunlu dersler kapsamına alınması ve iletişim mezunlarınca verilmesi gerektiği gibi hususlarda tartışmalar halen devam etmektedir.

Bu araştırmanın yapıldığı okullarda medya okuryazarlığı dersini veren öğretmenlerin hiçbirinin iletişim fakültesi mezunu olmadığı ve ders ile ilgili herhangi bir eğitim almadığı görülmüştür. $\mathrm{Bu}$, dersin daha yeterli bir şekilde verilebilmesi açısından olumsuz bir durumdur. Ağırlıklı olarak sosyal bilgiler branşı öğretmenleri tarafından okutulan dersi, Türkçe ve sınıf öğretmenlerinin yanı sıra diğer branşlardan öğretmenler de vermektedir. ${ }^{5}$ Medya okuryazarlığı dersinin daha verimli bir şekilde işlenebilmesi açısından bu derse giren öğretmenlerin iletişim fakültesi mezunu olması

5. 2008 yılı itibariyle ilköğretim okullarında medya okuryazarlığı dersini veren öğretmenlerin branşları ve sayıları şöyledir: Sosyal Bilgiler öğretmeni 6111, Türkçe öğretmeni 2730, sınıf öğretmeni 1153, diğer branşlar 2159 (Kaynak: RTÜK İzleme Değerlendirme Dairesi Başkanlığı, akt. Altun (2008). 
ya da dersle ilgili bir eğitimden geçirilmesi yararlı olacaktır. İnan'ın(2010:71) sınıf öğretmenliği ve sosyal bilgiler öğretmenliği bölümünde okumakta olan öğretmen adaylarıyla yaptığı araştırmada, öğretmen adaylarının \% 57,9'unun dersi iletişim fakültesi mezunlarının vermesi gerektiğini düşündükleri görülmüştür. Aynı araştırmada dersi sosyal bilgiler öğretmenlerinin vermesi gerektiğini düşünen öğrencilerin oranı ise \% 25,6'dır.

Medya okuryazarlığı dersinin zorunlu ders niteliği kazanamaması ise bir diğer önemli sorundur. Milli Eğitim Bakanı Nabi Avcı'nın medya okuryazarlığı dersi ile ilgili bir soru önergesine verdiği yanıta göre de dersin zorunlu dersler grubuna alınmasıyla ilgili herhangi bir çalışma yapılmamaktadır (www.egitimhane.com). Çocukların medya okuryazarlığı dersini alması, dersin zorunlu dersler kapsamına alınması ile sağlanabilir. Dersin ilköğretim birinci kademeden itibaren müfredatta yerini alması eleştirel medya okuryazarları yetiştirmek adına yararlı olabilir.

Bu araştırmada; öğrencilerin günlük hayatlarının önemli bir bölümünü televizyona ayırdıkları görülmüştür. Öğrencilerin tamamına yakınının evinde televizyon bulunmakta ve öğrenciler günün 1-3 saatini televizyon karşısında harcamaktadır. Aynı zamanda da televizyon eğlenmek için izlenen bir kitle iletişim aracıdır.

Öğrenciler dersin program seçiminde ve televizyon izleme sürelerinde değişikliğe yol açtığını ve televizyon izlerken program seçiminde akıllı işaretlere dikkat edilmesi gerektiğini belirtmiştir. Diğer taraftan öğrencilerin medya metinlerinin ideolojik mesajlar içerdiğini belirtmesi, medyanın içeriklerinin kurgu olduğunu ifade etmeleri, medyanın tarafsız olmadığını düşünmeleri, medyada yer alan haberlerin doğruluğunun sorgulanması gerektiğini belirtmeleri medya okuryazarlığı dersinin öğrencilerin eleştirel bir medya okuryazarı olabilmeleri açısından yararlı olduğunu göstermektedir. Öğrenciler, dersin medyayı sorgulamalarını sağladığını ve medya içeriklerine karşı eleştirel bir bakış açısı kazandırdığını düşünmektedir. Sadriu'nun (2009: 161) yaptığı araştırmada da benzer bulgular elde edilmiştir. Araştırmaya katılan ilköğretim ikinci kademe öğrencileri medya okuryazarlığı eğitiminin medyaya karşı bilinç ve eleştirel bir bakış açısı kazandırdığını ifade etmiştir.

Dersin daha başarılı olabilmesi açısından hiç kuşkusuz ki dersin müfredat programı büyük önem taşımaktadır. Türkiye'de uygulanmakta olan medya okuryazarlığı dersinin müfredat programı incelendiğinde dersin eleştirel bir medya okuryazarı yetiştirmekten daha çok korumacı bir yaklaşım çerçevesinde bilinçlendirmeye yönelik olduğu görülmektedir (MEB ve RTÜK, 2006). Bu doğrultuda medya okuryazarlığı dersinin müfredatında güncellemeler yapılarak öğrencilere eleştirel bakış açısı kazandırabilecek uygulamalara yer verilmelidir. Farklı televizyon kanallarının haber bültenlerinde ve gazetelerde belirli bir konuya ne şekilde yer verildiği, kullanılan dilin televizyon kanallarına ya da gazetelere göre ne şekilde farklııklar gösterdiği üzerinde durulmalıdır. Öğrencilere filmler ve reklamlar izletilerek yorumlamaları istenmelidir.

Medya okuryazarlığı ile ilgili çalışmalar sadece çocuklarla sınırlı kalmamalıdır. Yetişkin bireylerin yanı sıra medya çalışanlarının da medya okuryazarlığı konusunda bilgilendirilmesi ve medya okuryazarı niteliği kazanmaları gerekmektedir. Medya okuryazarlığı ile ilgili olarak kitle iletişim araçlarında bilgilendirici yayınlar yapılması çocukların ve ebeveynlerin bilinçlenmesinde önemli katkı sağlayabilir. 


\section{Kaynakça}

Altun, Adnan. (2008). Türkiye'de Medya Okuryazarlığı. İlköğretmen Eğitimci Dergisi, sayı 16, 30-34.

Asrak Hasdemir, Tuba. (2012). Gelenekselden Yeni Medya Okuryazarlığına: Türkiye Örneğinde Bir Değerlendirme. Hitit Üniversitesi Sosyal Bilimler Enstitüsü Dergisi, yıl 5, sayı 2, 23-40.

Aydoğdu, Erhan. (2014). Medya Metinlerinin Bilinçli Okunmasında Medya Okuryazarlığı Dersinin Etkisi Üzerine Bir Analiz (Ankara İli Örneği). Gazi Üniversitesi Sosyal Bilimler Enstitüsü, Yayınlanmamış Yüksek Lisans Tezi, Ankara.

Ayhan, Bünyamin. (2011). Konya'da Yerel Gazete Okuma ve Yerel Televizyon İzleme Davranışları. Medya Okuryazarlı̆̆ı, (ed.) Nurçay Türkoğlu, Melda Cinman Şimşek, İstanbul: Parşömen, 1. Baskı, 135-152.

Binark, Mutlu ve Bek Mine Gencel. (2010). Eleştirel Medya Okuryazarlığı, İstanbul: Kalkedon, 2. baskı.

Güngör, Nazife. (2011). İletişim Kuramlar ve Yaklaşımlar, Ankara: Siyasal.

Hobbs, Renee. (2004). Medya Okuryazarlığı Hareketinde Yedi Büyük Tartışma. Ankara Üniversitesi Eğitim Bilimleri Fakültesi Dergisi, çev. Melike Türkan Bağlı, cilt 37, sayı 1, 22-140.

İnal, Kemal. (2009). Medya Okuryazarlığı El Kitabı, 1. baskı Ankara: Ütopya.

İnan, Taşkın. (2010). Öğretmen Adaylarının Medya Okuryazarlık Düzeyleri ve Medya Okuryazarlığına Illişkin Görüşleri, Dumlupınar Üniversitesi Sosyal Bilimler Enstitüsü Yüksek Lisans Tezi, Kütahya.

Inceoğlu, Yasemin. (2011). Medyayı Doğru Okumak. Medya Okuryazarlığı, (ed.) Nurçay Türkoğlu, Melda Cinman Şimşek, 1. baskı, İstanbul: Parşömen, 19-24.

Kaya, Kamil ve Tuna, Meyrem. (2008). İlköğretim Çağındaki Çocukların Sosyalleşmesinde Televizyonun Etkisi. SDÜ Fen Edebiyat Fakültesi Sosyal Bilimler Dergisi, Mayıs, sayı: 17, 159-182.

Kuruoğlu, Huriye. Televizyonun Çocuklar Üzerindeki Olumsuz Etkileri. www.scholar.google.com.tr Erişim tarihi: 9 Mart 2014.

MEB TTK ve RTÜK. (2006). İlköğretim Medya Okuryazarlığı Dersi Öğretim Programı ve Kılavuzu, Ankara.

MEB TTK ve RTÜK. (2007). İlköğretim Medya Okuryazarlığı Dersi Öğretmen El Kitabı, Ankara.

MEB. İlköğretim Kurumları (Illkokul ve Ortaokul) Haftalık Ders Çizelgesi, http://ikgm.meb.gov.tr/upload/ TTK\%C3\%A7izelge.pdf. Erişim tarihi: 20 Eylül 2013.

Mutlu, Erol. (1999). Televizyon ve Toplum. Türkiye Radyo Televizyon Kurumu, 1. baskı.

Özarslan, Ersin. (2008). Mehmet Said Paşa Gazeteci Lisanı, Gazi Üniversitesi İletişim Fakültesi Kırkıncı Yıl Kitaplığı No:17, Ankara.

Özer, Ömer. (2011). Televizyonun Şiddet Özelinde Bilinç Altına Yaptığı Etkiye Yönelik Yetiştirme Kuramı Çerçevesinde Yapılan Araştırma. Medya Okuryazarığı, (ed.) Nurçay Türkoğlu, Melda Cinman Şimşek, 1. baskı 
istanbul: Parşömen, 273-289.

Pekman, Cem. (2011). Avrupa Birliği’nde Medya Okuryazarlığı. Medya Okuryazarlı̆ıı, (ed.) Nurçay Türkoğlu, Melda Cinman Şimşek, 1. baskı, İstanbul: Parşömen, 37-45.

RTÜK, Televizyon İzleme Eğilimleri Araştırması 2, http://www.rtuk.org.tr/sayfalar/lcerikGoster.aspx?icerik_ id=88e435c1-2a20-4956-92e0-6c3d295ca079 Erişim tarihi: 10 Mart 2014.

Sadriu, Selma. (2009). Seçmeli Medya Okuryazarlığı Dersi Alan Illköğretim İkinci Kademe Öğrencilerinin Ders Sonu Çıktılarına Yönelik Bir "Pilot Araştırma", İstanbul Üniversitesi Sosyal Bilimler Enstitüsü Halkla Ilişkiler ve Tanııım Ana Bilim Dalı Yüksek Lisans Tezi.

Taşkıran, Nurdan Öncel (2007). Medya Okuryazarlığına Giriş, 2. baskı, İstanbul: Beta.

Taylan, Hasan Hüseyin. (2011). Televizyonla Yetişmek: Televizyon Şiddetinin Etkileri Üzerine Bir Araştırma, Konya: Çizgi.

TDK. (2003). Türk Dil Kurumu, Güncel Türkçe Sözlük, www.tdk.gov.tr/tdksozluk (Erişim,10 Temmuz 2012).

Tokgöz, Oya. (2010). Temel Gazetecilik, İmge Kitabevi Yayınları, 8. baskı.

Treske, Gülden. (2011). Medya Okuryazarlığı: Neden Gerekli. Medya Okuryazarlığı, (ed.) Nurçay Türkoğlu, Melda Cinman Şimşek, 1. baskı, İstanbul: Parşömen, 25-35.

Uyanık, Muvaffak. (2007). Yeni Okulun Ders Vasıtalarından Gazete, Gazi Üniversitesi Iletişim Fakültesi Kırkıncı Yıl Kitaplığı No:3, Ankara.

http://www.medyaokuryazarligi.org.tr/documents/yayinlar/bruksel_deklerasyonu.pdf Erişim tarihi: 19 Eylül 2012.

http://www.egitimhane.com/bakandan-medya-okur-yazarligi-dersi-aciklamasi-h5488.html Erişim tarihi: 10 Nisan 2014. 